\title{
PARTY SUPPORT AND VOTER BEHAVIOUR IN THE WESTERN CAPE \\ Trends and patterns since 1994
}

Cherrel Africa

\begin{abstract}
Cherrel Africa is a Senior Lecturer in the Department of Political Studies, University of the Western Cape e-mail: cjafrica@uwc.ac.za
\end{abstract}

\begin{abstract}
Since 1994 election outcomes in the Western Cape have been examined through analyses of the 'coloured vote'. These explanations, which are premised on the racially based motivations of voters, feed into the choices, rhetoric and behaviour of political parties. Besides inadvertently providing justification for racially inflammatory campaign strategies they allow parties to neglect their duty to give voters adequate information. In this article I provide an overview of voting trends and the political developments which have underpinned these patterns. I argue that it is not the nature of the electorate but national political developments and political parties, through their behaviour and campaigns, that are responsible for gains and losses and for the dramatic political changes in the province. I further argue that it is precisely because racial identity is so salient in the Western Cape that parties need to move towards more inclusive campaign strategies.
\end{abstract}

\section{INTRODUCTION}

The Western Cape is a politically unique province where electoral trends stand in sharp contrast to those in the rest of South Africa. While national outcomes have been predictable, returning the African National Congress (ANC) to power with large majorities, outcomes in the Western Cape have been far less predictable, with all democratic elections being highly contested. This has resulted in three different political parties (namely the National Party - NP, which later became the New National Party - NNP; the ANC and the Democratic Alliance - DA) assuming power in the province. There is no certainty about the election outcome prior to the election, as is the case at national level. 
The reason for this alternation in power is said to lie with the coloured majority in the province. Breytenbach (1999, p 117), for example, argued that the coloured vote was of special significance 'because the outcome of the Western Cape hinged very much on this factor'. Perceptions of the importance of the 'coloured vote' have resulted in campaigning that often encompasses unintentional or deliberate racial mobilisation and inflammatory political rhetoric.

Explanations of election outcomes and voting patterns in the Western Cape (as elsewhere) tend to revolve around racial fault lines and the racially based motivations of voters. These explanations in turn feed into the choices and actions of political parties. For example, Reynolds (1999, p 190) noted that in the 1999 election both the ANC and the NNP fielded coloured candidates for the premiership 'because it reflected the political reality that coloured voters are in the majority in the Western Cape'. Nijzink \& Jacobs (2000, p 39) note that the ANC in the Western Cape engineered a number of high profile defections of NNP politicians 'in a careful strategy to make inroads among coloured voters'. In 2009 this remained the case.

Daniel \& Southall (2009, p 268) note that the ANC made a series of decisions relating to Ebrahim Rasool 'to make up lost ground among coloureds' and that the selection by the Congress of the People (Cope) of Allan Boesak as the party's premier candidate was a significant blow to the ANC because he 'retained a major following especially from the coloured community'. Such explanations allow the contesting political parties to justify racialised campaigning and raise the question of whether election outcomes in the Western Cape are the result primarily of the actions of voters or of political parties.

Thus, a critical component of any analysis of elections and voting in South Africa and, specifically, in the Western Cape, is the role of identity in determining voting patterns. Analysts such as Schlemmer (1999, p 288) see South African voter motivations as 'determined by symbolic or identity concerns', resulting in election outcomes being described as assuming the quality of a 'racial or ethnic census'. Friedman (2005, p 5) argues that while South African elections are not simplistic ethnic censuses elections are not determined by policy issues. According to Friedman $(2005, \mathrm{p} 3)^{\prime}$ 'voter preferences are shaped by considerations other than competing technical solutions to economic and social problems' because South Africans vote on the basis of race, language and religion. Others have challenged this view, arguing that values, perceived interests and judgements as well as many other factors have important effects on partisan support (Eldridge \& Seekings 1995; Mattes \& Gouws 1998; Mattes 1995; Mattes \& Piombo 2001; Mattes, Taylor \& Africa 1999; Habib \& Naidu 1999; Hoeane 2004).

A significant problem is that the starting point of all these analyses is the behavioural motivations and / or demographic characteristics of the electorate. 
This preoccupation with individual decisions is flawed because, as Sniderman (2000, pp 68-69) argues, political institutions - rather than voters - fix and organise the confusion of politics. While individual decision-making processes are critically important, voters are only one part of the electoral equation; political parties and the choices they offer constitute the other part. This raises concerns about the adequacy of accounts which view election outcomes as primarily determined by the characteristics of the electorate.

Another more serious problem created by this debate is that it opens up the space for political parties to abscond from their duty to provide voters with adequate information. If Friedman is correct that considerations other than competing solutions to economic and social problems shape voter preferences parties need not defend their records or provide information about how they will deal with the problems facing the electorate.

In this article I will examine voting trends and political developments in the Western Cape to offer some insight into whether the outcomes are primarily dependent on voters or parties.

\section{THE CONTEXT}

The Western Cape is a demographically unique province, with coloured voters forming the majority. According to the South African Institute of Race Relations's South African Survey of 2007/ 2008 the total population of the Western Cape was 4540 286, with more than half (2 437 741) coloured, just under a quarter (1 076 194) African, 978094 white and 48257 Indian. The 2007/ 2008 survey also estimated that 55.3 per cent of people in the Western Cape speak Afrikaans, 23.7 per cent speak isiXhosa and 19.3 per cent speak English. However, it should be noted that the Afrikaans spoken on the Cape Flats is quite different from the Afrikaans spoken in the suburbs - in other words, there is a clear distinction between 'white Afrikaans' and 'coloured Afrikaans'.

Data from round four of the Afrobarometer survey in South Africa reveal a lower level of party identification in the Western Cape than in other regions in South Africa. By the end of 2008, 60 per cent of the South African electorate indicated that they felt close to a political party. As Figure 1 shows, the Western Cape was the only province where less than half $(48 \%)$ of the respondents said they felt close to a political party compared to more than 70 per cent in the Free State, Eastern Cape and Mpumalanga and 60 per cent or more in the North West, KwaZulu-Natal and the Northern Cape. Gauteng and Limpopo also had 'lukewarm' levels of identification, with just over half of the respondents saying they identified with a political party. These 'non-partisan' voters in the Western Cape are more likely to be open to persuasion during election campaigns. 


\section{Figure 1}

\section{Party identification by province (2008)}

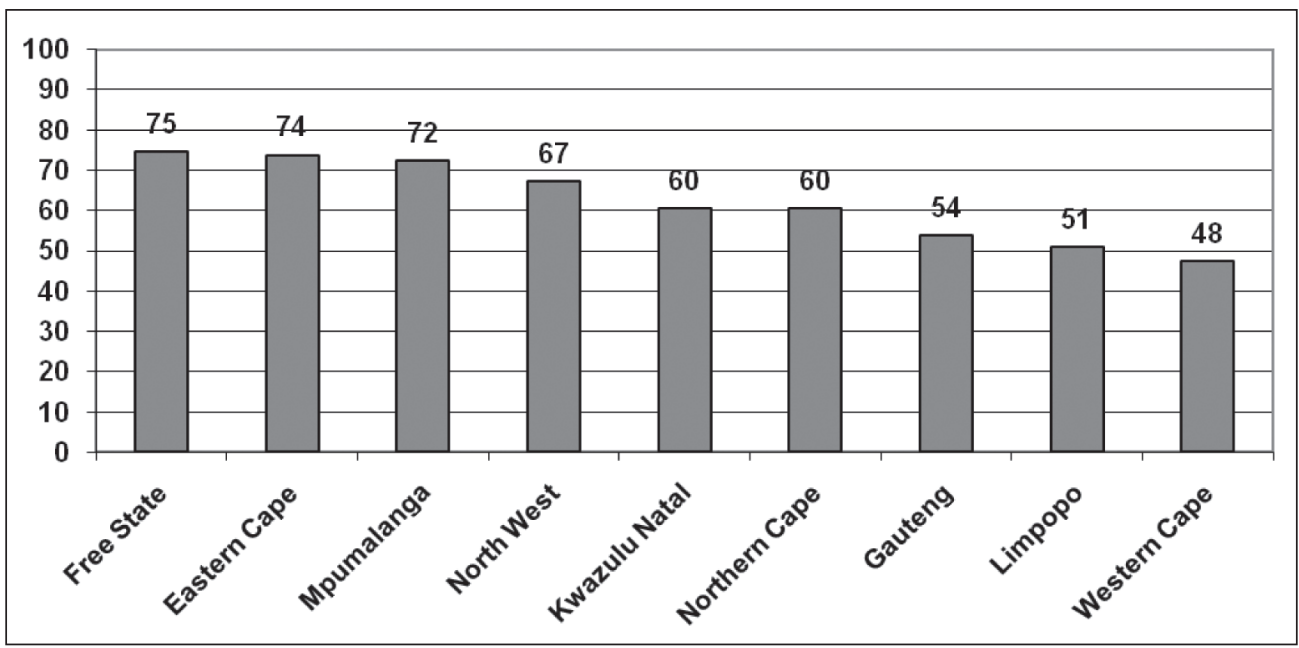

Source: Afrobarometer 2008. Sample size 2400.

At the same time, the turnout in the Western Cape has been higher than that in other provinces. Voter registration and turnout there has been continuously high compared to national patterns. At the national level turnout has declined sharply since the first democratic election, in 1994. Participation as a proportion of the voting age population (VAP) declined from 86 per cent in 1994 to 72 per cent in 1999. It then declined more dramatically, to 58 per cent, in 2004, increasing slightly, to 60 per cent, in 2009 (Schulz-Herzenberg 2009, p 26). Thus, participation in national elections, counted as a percentage of VAP, decreased substantially between 1994 and 2004 while turnout, as a proportion of VAP, has been consistently high in the Western Cape, where it declined from 89 per cent in 1994 to 70 per cent in 1999, increasing to 73 per cent in 2004 and 75 per cent in 2009.

Table 1

Voting age population, registration and turnout in the Western Cape

\begin{tabular}{|l|c|c|c|}
\hline & Registered & Votes cast & Estimated turnout \\
\hline $\mathbf{1 9 9 4}$ & NA & 2137742 & $88.90 \%$ \\
\hline $\mathbf{1 9 9 9}$ & 1864019 & 1616179 & $69.70 \%$ \\
\hline $\mathbf{2 0 0 4}$ & 2220283 & 1621835 & $73.40 \%$ \\
\hline $\mathbf{2 0 0 9}$ & 2634439 & 1987777 & $75.45 \%$ \\
\hline
\end{tabular}

Source: Reynolds 1994, 1999; Piombo 2005; Daniel \& Southall 2009 
These unique features combine to create extremely competitive elections, notably in an attempt to capture the coloured vote. A high turnout combined with an uncertain outcome typically results in competitive elections and greater accountability. Whether these competitive elections resulting in the alternation of power have produced greater responsiveness or accountability or increased instability is an open question which merits a separate investigation. Unfortunately, the perceived salience of race and the importance of the coloured vote have negative implications for the behaviour and campaign strategies of political parties, which, in their attempts to capture the coloured vote, make decisions in terms of what they perceive will appeal to coloured voters. The race issue also results in campaigning that includes appeals by the contesting political parties to racial prejudice.

\section{COMPARING NATIONAL AND PROVINCIAL OUTCOMES}

At the national level concerns have been raised about the negative implications of declining levels of voter participation in the context of continuous electoral dominance by the ANC. The ANC's proportion of the vote, taken as a proportion of total votes cast, increased from 62 per cent in 1994 to 66 per cent in 1999, to 70 per cent in 2004, dropping back to 66 per cent in 2009. Votes cast for opposition parties decreased from 32 per cent in 1994 to 24 per cent in 1999 and 17 per cent in 2004, increasing to 20 per cent in 2009 (Schulz-Herzenberg 2009, p 26). As Mattes (2005, p 106) indicates, turnout trends and voting patterns are not unrelated. Votes cast for the ANC (viewed as a proportion of votes cast by all eligible voters) decreased dramatically between 1994 and 2009. Piombo (2005, p 279) also argues that 'the decreased share of the vote earned by the opposition as a whole would suggest that it is mainly opposition voters who stayed at home'. By 2009 more people stayed at home than voted for the ANC at the national level.

\section{Table 2}

\section{Election results in the Western Cape}

\begin{tabular}{|l|r|r|r|r|}
\hline & $\mathbf{1 9 9 4}$ & $\mathbf{1 9 9 9}$ & $\mathbf{2 0 0 4}$ & \multicolumn{1}{c|}{$\mathbf{2 0 0 9}$} \\
\hline NP/NNP & 1138242 & 609612 & 170469 & NA \\
\hline ANC & 705576 & 668106 & 709052 & 620918 \\
\hline DP/DA & 141970 & 189183 & 424832 & 1012568 \\
\hline ID & NA & NA & 122867 & 92116 \\
\hline Cope & NA & NA & NA & 152356 \\
\hline
\end{tabular}


The Western Cape, on the other hand, has experienced alternation of power, with three different parties - the NP, the ANC and the DA- having been in power. This alternation of power has occurred in the context of fairly high turnout levels. As seen in Table 2, by 2009 the DA had won an outright majority, steadily increasing its proportion of the vote across the four elections.

\section{THE FIRST DEMOCRATIC ELECTION (1994)}

In the first democratic election, held in 1994, the NP won an outright majority in the Western Cape - 53.3 per cent of the votes for the Western Cape provincial legislature against the ANC's 33 per cent. The DP only secured 1.7 per cent of the national vote and 6.6 per cent at provincial level. The African Christian Democratic Party (ACDP) won 1.2 per cent in the Western Cape while other parties mustered a combined 5.9 per cent.

The provincial result in the Western Cape, which put the NP into power under the leadership of Hernus Kriel, shocked many activists and, indeed, many analysts, who had presumed that coloured voters, scarred by the effects of apartheid, would secure an ANC government in the province. Language and culture were cited as reasons for the turn of events. With regard to the Democratic Party (DP, later the Democratic Alliance - DA) Welsh (1994, p 107) labelled its results 'an unmitigated disaster', ascribing this to the fact that the election had assumed the character of a presidential race between Nelson Mandela of the ANC and F W de Klerk of the NP. Welsh (1994, p 115) estimated that the fact that the DP had only won about 3 per cent of the coloured vote was a result of its inability to 'break out of the urban, English-speaking, white, middle-class confines of liberalism'.

The result was labelled a racial/ ethnic census with the coloured community feeling happier with Afrikaner than rather than African nationalism (see, eg, Johnson (1996, p 310)). This claim was questioned by authors such as Mattes, Giliomee \& James (1996) and Eldridge \& Seekings (1995), who raised questions about the difficulties of making a priori predictions about so-called 'middle groups' like coloured and Indian voters. Eldridge \& Seekings $(1995, \mathrm{p} 2)$ believe the Western Cape posed several specific challenges to the ethnic/racial census argument, arguing that, at the outset of the election campaign only one-third or one-half of the provincial electorate expressed the intention to vote for their 'natural' racial parties (depending on how one decides which parties were the voters' 'natural' choices) and that pre-election polling data suggested that voters' attitudes on a range of issues, not simply their ethnic identity, underlay their voting intentions. Furthermore, Mattes, Giliomee \& James (1996, p 146) argue that: (i) if the importance of race emanated from the role given to it by apartheid one would expect the election to pit both coloured and black victims of apartheid 
against their former white oppressors; (ii) coloured people did not cast their vote monolithically for one party; and (iii) the three largest parties did not derive an overwhelming proportion of their support from any single racial group.

Another explanation related to an 'affinity' or 'closeness' between coloured and white voters who share Afrikaans as a language (Reynolds 1994). This explanation was empirically refuted by Mattes, Giliomee \& James (1996, p 146) based on survey data which showed that party preferences among coloured people differed little by language.

Putting aside language and cultural affinity, the 1994 election results in the Western Cape make sense if one considers the underlying fears of voters revealed by opinion polls conducted in the province in December 1993. The NP took advantage of these fears through an extremely effective election campaign. A provincially representative opinion poll of respondents conducted for the Institute for Multi-party Democracy in December 1993 revealed a significant concern about violence. Overall, 53 per cent of respondents cited violence as their primary concern.

Importantly, as shown in Figure 2, 27 per cent considered that the ANC was likely to initiate violence. As indicated by Africa (1996, p 49) this was almost on a par with the 29 per cent who felt that the right-wing Afrikaner Weerstandsbeweging (AWB) would initiate violence. Furthermore, 34 per cent saw the ANC as being responsible for encouraging political violence compared to 7 per cent who thought the NP was doing so. At the same time, almost half (49\%) felt that the NP was discouraging political violence, while 23 per cent felt the ANC was doing so.

To be sure, these fears were highly racialised and the NP did a sterling job of capitalising on them, using inflammatory campaign rhetoric throughout a predominantly negative campaign against the ANC which depicted the ANC as a violent and dangerous party that would plunge South Africa into a state of chaos. According to Mattes, Giliomee \& James (1996, p 133) the main aim of the NP was to force voters to determine which party would be most trustworthy to run the government and therefore painted a stark choice between a new, competent and trustworthy NP and an old, dangerous ANC that could not govern.

The vast series of endorsement-type advertisements for the NP utilised images of terrorism, intimidation, burning of collaborators, boycotts and strike action, referring to 'the comrades' as being responsible for violence in the country. The negative depiction of the ANC as being linked to 'the comrades' was strengthened by scores of street posters with the slogan 'Stop the comrades'. The NP's campaign was bolstered by events surrounding the squatter occupation of houses built for coloured people (Giliomee 1994, pp 66-67). Another of the NP's key campaign messages was that the economic policy of the ANC and the South 
African Communist Party (SACP) would bring the country to its knees, and that the NP had the experience and ability to create order and economic prosperity out of chaos (Giliomee 1994, p 62). The NP emphasised the link between the ANC and the SACP by focusing on the dangers of communism, the number of SACP candidates on the ANC's list of candidates, and their influence on the ANC.

At the same time, a reservoir of positive emotions was directed towards F W de Klerk for ushering in a new era in South African politics. According to Breytenbach (1999, p 117), as early as 1991 an opinion poll revealed that 55 per cent of coloured voters would prefer to have De Klerk as leader, compared to 3 per cent who preferred Nelson Mandela. As Nijzink \& Jacobs (2000, p 37) indicate, 'for coloureds, De Klerk seemed to be the embodiment of the transformed National Party'.

The ANC's campaign revolved primarily around the party's proposed Reconstruction and Development Programme (RDP) which, among other things spelled out a succession of measures to create jobs through public works (Lodge 1994, p 30). According to Silke \& Schire (1994, p 133) the ANC's detailed policy 'open plan' advertisements, based on the tenets of the RDP, which emphasised jobs, workers' rights, land reforms, housing policies and welfare, portrayed the party as ready to govern and as well prepared on a broad range of policy issues.

Figure 2

Perceptions of who might start violence (December 1993)

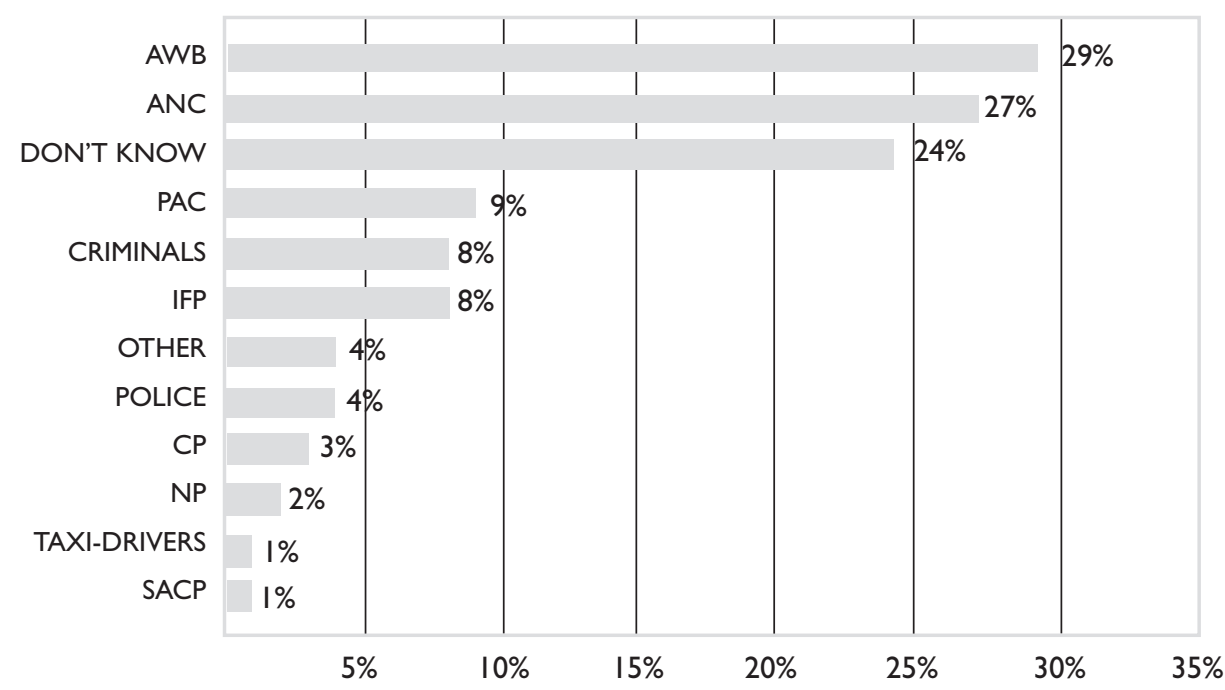


The second phase of the ANC's campaign, described as 'attack, contrast and endorsement', comprised attacks on the NP, contrasting the ANC's RDP with the NP's alleged lack of a plan, and endorsement of the ANC by community leaders at rallies and in the press. The 'contrast' component was part of a national shift in strategy, but the Western Cape put a particularly aggressive spin on it, emphasising attack (Eldridge \& Seekings 1995, p 15). A series of advertisements focused on the fact that 'unemployment has struck at the heart of coloured, African and Indian communities in the Western Cape. The National Party's disastrous economic policy is responsible for this.'

Attention was paid to the NP's record of forced removals, corruption, involvement in 'third force' activities, covert operations it undertook, its backing from 'Witdoek' vigilante leaders and the support of Hernus Kriel, the NP's candidate for premier of the province, for the notorious Section 29 law, which related to detention conditions. As Eldridge \& Seekings (1995, pp 15-16) point out the final phase of the ANC's campaign 'was marked by intensified attacks on the NP, further endorsements by community leaders, and upbeat messages about the future under an ANC government'.

The NP's campaign convinced voters in the Western Cape that the ANC would allow the country to descend into anarchy. On the other hand, the ANC's focus on issues such as 'third force' activities in the Western Cape probably counted against it. It is likely that the issue of 'third force' activities had meaning for activists and black citizens but little relevance for white and coloured people - none of the respondents in the abovementioned study by the Institute for Multiparty Democracy named a third force as being responsible for starting violence.

Thus, in the Western Cape the National Party was more successful than the ANC in mobilising people to vote for it. Given the concerns about violence and the pre-existing belief that the ANC would be most likely to start it, the NP's campaign messages about the ANC's involvement in boycotts, strikes, arson and other acts of violence fell on fertile ground.

\section{THE 1999 ELECTION: REALIGNMENT IN THE WESTERN CAPE}

By the second democratic election the DP had made modest advances in the province, doubling its share of the vote to 12 per cent. However, the contest remained primarily one between the ANC and the NP, now renamed the New National Party (NNP). Following the 1999 election the distribution of power shifted dramatically, with the NNP losing its majority status. Its share of the vote dropped by 15 per cent to 38 per cent -4 per cent less than that of the ANC. The ANC increased its share of the vote by 9.1 per cent to 42 per cent. These massive shifts took place in the context of fairly high turnout levels. 
Yet the campaign period was far less remarkable than that in 1994. As Habib \& Naidu (1999, p 190) note, 'South Africa's second democratic election was very much a placid affair'. During the 1999 election campaign there was an increased focus on 'the issues'. Taylor \& Hoeane (1999, p 133) note that all the political parties addressed the key social issues of job creation, crime, housing, education, service delivery, and corruption. This political realignment pointed to the idea that explanations of voting patterns in the Western Cape are deficient. The notion that coloured votes were based primarily on the cultural and / or linguistic affinity between coloured and whites was challenged by the fact that the pendulum had swung in the ANC's favour.

On the campaign front, the ANC in the Western Cape, learning from its campaign-trail mistakes of 1994, took a softer approach, with appeals for voters in the province simply to give it a chance. As Lodge $(1999$, p 66) indicates, particular emphasis was placed on 'listening'- party leaders concentrated on meetings with select groups of community and religious leaders, while branch members focused on household visits.

In addition to a new name, the NNP adopted a new multiracial focus. A poster with its leader Marthinus van Schalkwyk at the centre was at pains to show that the party was fielding candidates of other races (coloured and black). The NNP manifesto for 1999 professed that it was the most multiracial party in South Africa, representing 'a broad and inclusive South African patriotism that transcends race, language and religion' (New National Party 1999, p 213). While the intentions behind this contention were noble, they communicated a substantial break with the party's previous uncompromising commitment to 'separate development'. The new focus also sat uncomfortably with the NNP's emphasis on protecting minority rights. The National Party's decision to change its name was not necessarily a good strategic choice. It signalled an admission that it had erred and needed to improve.

In 1999 the spotlight was turned on the dangers of one-party dominance and a concentration of power if the ANC were to gain a two-thirds majority. These arguments were primarily highlighted by the Democratic Party (DP) and echoed by the NNP and the United Democratic Movement. Under the leadership of Tony Leon the DP built its strategy around 'robust opposition' with a focus on government failings, incompetence, corruption and a lack of urgency (Schrire 2001, p 142). According to Welsh (1999, p 91) the DP, in 1996, began to fashion a new approach to election campaigns, which involved the presentation of two clear competing visions: the ANC's collectivism and the DP's democratic liberalism. This formed the basis of its aggressive 'fight back' campaign in the 1999 elections. Posters with a serious-looking Leon cited an article printed in Die Burger in which Marthinus van Schalkwyk was quoted as saying that '... a situation can develop 
where the NNP ... can serve in an ANC-led government on invitation'. It urged voters not to let the NNP disappoint them again and stated that 'only Tony Leon and the DP have ruled out a coalition with the ANC'.

What then accounts for the dramatic shifts in the Western Cape? In the 1999 election organisational and political changes probably mattered more to voters than campaign messages. It is likely that several other factors underpinned the political changes that occurred in the province.

Firstly, voters in the province could observe the fact that the dire predictions of the National Party for South Africa under ANC rule had failed to materialise. In its 1994 campaign the NP had painted a bleak future for South Africa under an ANC-led government. Voters in the Western Cape could watch the ANC as incumbents at national level. Instead of descent into chaos, post-1994 South Africa became a beacon of political hope around the world. As Magubane (2000, p 28) aptly notes, 'the "new" South Africa was born amidst profound relief, a palpable desire for reconciliation, overwhelming optimism and genuinely high hopes for the future'.

The Mandela era ushered in a new constitutional framework which included the protection of a broad range of rights, the development of mechanisms for public participation in government processes and the establishment of various protective institutions such as the Human Rights Commission, the AuditorGeneral, the Public Service Commission and the Public Protector. By 1999 the government had undergone a fundamental and radical overhaul (Calland 1999, p 1).

This positive image was further cemented by Nelson Mandela's heroic international status. Indeed, the primary thrust of Mandela's administration was national reconciliation. Mandela personally undertook a series of imaginative reconciliatory gestures such as visiting the man who had prosecuted him during the Rivonia Trial and rallying South Africans around the 1995 Rugby World Cup Final (Lodge 2002, p 14). Lodge indicates that Mandela's stature among South Africans remained undiminished and public satisfaction with his performance as president stood at 80 per cent just prior to the 1999 election.

At the same time, a second set of national-level events had undermined the credibility of the NNP. In May 1996 F W de Klerk had informed a packed press conference that he was taking the NP out of the Government of National Unity (Calland 1999, p 6). Calland notes that this was not a unanimous decision-many NP leaders wished to stay in power. In September 1997 De Klerk resigned and was replaced by Van Schalkwyk (Southall 1998, p 462). According to Breytenbach (1999, p 119) De Klerk's absence as the party leader weakened the NNP among coloured voters and threatened its retention of its Afrikaner support base, while attracting support from other quarters. 
The question of who to target as its support base aggravated divisions within the party and ultimately resulted in the resignation of Roelf Meyer, who had played a central role in the negotiation process and in developing the interim constitution. Meyer had advocated the dissolution of the NP and the formation of a coalition movement made up of all opposition parties (Ndletyana 1999, p 183). Furthermore, according to Welsh (1999, p 91), the NNP was now reduced to a relatively small opposition party 'which could no longer offer the patronage, protection and privilege it could when it was the ruling party'. These events damaged the party's image.

Thirdly, the woes inflicted on the NNP by organisational problems and defections were exacerbated by the steady outpouring of horrific revelations to the Truth and Reconciliation Commission (TRC) about atrocities committed by the apartheid government (Welsh 1999, p 91). Following an extensive process of statement-taking, public meetings and visits by fieldworkers to various communities, most of the 76 public hearings were televised (Lodge 2002, p 180). As Breytenbach (1999, p 119) indicates, some NNP supporters were 'shamed by the revelations of the TRC'.

All these elements eroded the NNP's support base in the 1999 elections while the DP made marginal inroads with more focused campaign efforts. The ANC, by means of its softer provincial campaign approach, began to gain the confidence of voters as they watched ANC incumbents at national level. Nonetheless a NNP / DA alliance kept the ANC out of power in the Western Cape and Marthinus van Schalkwyk became the new premier.

\section{THE 2004 ELECTION: A SHIFT IN PERCEPTIONS}

By 2004 the Democratic Party, now the Democratic Alliance, had made sizeable inroads in the Western Cape, increasing its support base to 27 per cent. The ANC also increased its support base marginally, from 42 per cent to 45 per cent, just short of an outright majority. The NNP's share of the vote crumbled to 11 per cent. The newly formed Independent Democrats (ID) under the leadership of Patricia de Lille, formerly of the Pan Africanist Congress, won 7.8 per cent of the vote in the Western Cape.

In 2004, as in 1994 and 1999, national events had a significant impact on the political landscape of the Western Cape. The Democratic Party and New National Party announced in June 2000 that they would join up as the Democratic Alliance, with the aim of building a political movement that would effectively challenge the ANC for political power. The DP's Tony Leon became the national leader and NNP's Marthinus van Schalkwyk the deputy leader. The objectives of the DA were to present a challenge to the ANC's electoral dominance and to strengthen 
opposition politics. The merger was never institutionalised and by November 2001 the alliance had sprung apart, primarily due to dissatisfaction among former NNP officeholders with Leon's leadership (Lodge 2002, p 157). Kotze (2001, p 123) indicates that the DP and NNP had no shared historical roots and very little ideological common ground. The merger and subsequent split had stretched the NNP's resources and the DA had effectively absorbed the NNP's grassroots structures (Schulz-Herzenberg 2005, p 166). The NNP's next move was to enter into an alliance with the ANC.

There was also a new dynamic. Given the fact that these were the third democratic elections parties were beginning to develop 'track records'. Voters could start to assess the consistency of party rhetoric and the outlandish inconsistencies in NNP rhetoric appear to have finalised the demise of the party. By 2004 the NNP, in coalition with its former arch-enemy the ANC, preached a campaign message that completely contradicted its messages of 1994 and 1999. The party's primary campaign theme in 2004 was that it provided a voice for voters via the coalition arrangement with the ANC, which, it maintained, had enabled it to strengthen its position and thus provide minority voters with a voice in government, though it was still distinct from the ANC.

The main thrust of the NNP's election campaign in 2004 was that the party would provide access to government decision-making processes and resources. It argued that the DA's aggressive style of politics was unsuitable and damaging to democracy and located itself as the mediator between voters and the ANC. Thus, the NNP's campaign message of co-operation with the ANC was completely inconsistent with preceding NP campaigns, which had been predominantly negative, depicting the ANC as a dangerous, violent, authoritarian, politically intolerant party with an economic policy that would bring the country to its knees, therefore making it not fit to govern (Giliomee 1994; Eldridge \& Seekings 1995).

The collaborative arrangement with the ANC, as well as the assertion that this would benefit voters, essentially communicated that the NNP's previous assessment of the ANC had been completely inaccurate. This is particularly important given Iyengar \& Valentino's (2000, p 110) argument that campaign communication is most persuasive when it interacts with voters' prevailing expectations and evokes what voters already 'know'. It is likely that these messages were regarded as farcical and therefore ineffective. Not only had the incumbent ANC government at national level proved the NNP's claims to be inaccurate, the NNP now expected voters to believe that it would provide'a voice' for them in government through the co-operative arrangement with the ANC.

Literature on the subject also informs us that campaign themes should be congruent with previous campaigns and messages within a campaign period should be well blended and internally consistent (Schnur 1999; Weaver 1996). Not 
only was the 2004 campaign incongruent with its predecessors, there was also a lack of internal consistency among the messages the NNP presented to voters during the 2004 campaign. The core messages, that the party had strengthened its position through its alliance with the ANC but that it was distinct from and would hold the ANC to account on issues such as the death penalty, abortion and affirmative action, were contradictory. As Southall \& Daniel $(2005, \mathrm{p} 48)$ state, the messages that the NNP was committed to constructive opposition, reconciliation and political consensus; that it differed from the ANC on key aspects such as being tougher on crime and the handling of Zimbabwe and that its presence in government gave important leverage to minority groups was as confusing as it was unconvincing. Schulz-Herzenberg (2005) also correctly points out that the NNP's stated ideological shift to the centre of the political spectrum was undermined by its overall policy stance.

On the other hand, the ANC ran a largely positive campaign on the theme of the celebration of ten years of democracy. It emphasised its achievements, acknowledged its shortcomings, and drew attention to its strength, experience and commitment. The main thrust of the ANC's 2004 campaign was that it was the only party able to improve the lives of ordinary people in South Africa. A key message related to its partnership with 'the people' in pursuing this goal. The campaign was significantly consistent with those of the elections of 1994 and 1999 with its theme of 'a better life for all'and the presentation of the role of the ANC in ending apartheid as well as the importance of contracts and partnerships with various social actors. As Lodge $(2005, \mathrm{p} 117)$ indicates, the language used also revived the 'people centred' rhetoric of the Reconstruction and Development Programme. However, slight changes were also evident. In the founding elections of 1994 a large focus was on the end of apartheid, as embodied in the slogan 'Now is the time', whereas in 2004 a more practical and hands-on approach was used to present the ANC as competent in its role as the government of the day. The message that 'the tide has turned' became institutionalised, indicating to voters that the ANC-led government was successful in ushering in change in South Africa (Booysen 2005, p 131).

In 2004 the DA contended that a vote for the NNP was as good as a vote for the ANC. It further contrasted itself with the ANC and other opposition parties, communicating the message to voters that other parties lacked sound policies, competence and integrity or that they simply served to fracture the opposition. The primary theme of the DA's 2004 campaign was 'South Africa deserves better'. The party's message strategy was three-pronged, ranging from the projection of its strengths and its policy alternatives to highlighting ANC weaknesses with reference to integrity and policy as well as the weaknesses of other opposition parties (Booysen 2005, p 136). 
The DA's primary assertion in 2004 was that it had the capacity and the appropriate policies to deal with South Africa's key problems. It stated that it was ready to take office because it had the means to deliver. It presented itself as an alternative government rather than merely an opposition party (Booysen 2005, p 137). In its manifesto, entitled A Better South Africa, the party gave a detailed outline of its policy positions (Democratic Alliance 2004). The manifesto presented the DA as South Africa's only serious alternative to the ANC, stating that the party was the only political organisation other than the ANC with political reach in every province and was therefore capable of forming the central pillar of a democratic alternative.

The manifesto acknowledged the progress and achievements of the past ten years but argued that 'for millions of South Africans, these successes have been overshadowed by the ANC government's broken contract with the people of South Africa: its failure to deliver the better life it promised in 1994'. The manifesto was also particularly critical of the ANC government's response to HIV and AIDS and argued that the ANC had accumulated power for itself while leaving the people of South Africa behind.

Overall, the DA's campaign was consistent with its previous campaigns, particularly in key areas such as the focus on the electoral dominance of the ANC, criticisms of ANC performance and the presentation of the DA as the only viable alternative to the ANC. The goal of a basic income grant represented a key shift. Analysts also point out that the emphasis on policy alternatives was a new area for the party (Davis 2005; Southall \& Daniel 2005). Furthermore, the party's campaign style was marginally softer than it had been during the 1999 'Fight Back' campaign. However, the ambiguous subtext of the DA's slogans and its messages are likely to have offended some voters. While it probably intended to refer to changes in the material living conditions of voters, the slogan 'Vote DA for real change' raised questions such as what type of change there had been prior to this and was the change from apartheid to democracy artificial. Furthermore, inherent in its theme (that South Africa deserved better) was criticism of the ANC. This slogan automatically raised the question: better than what? As Booysen (2005) argues the slogans were interpreted 'as being polarizing'. Edighji (2004) went as far as saying that the DA predicated its election campaign on 'fear-mongering' and 'alarmism'.

While the DA gave out a series of messages presenting itself as a policyoriented alternative ready to sort out the ANC's failed policies, there was a lack of internal consistency among the messages. As Booysen (2005, p 132) indicates, the party's policy solutions were 'overwhelmingly free market, which constituted a policy environment that was essentially incompatible with the party's proposal for a basic income grant'. Southall \& Daniel (2005, p 50) also argue, correctly, that 
adopting 'an unconvincing, somewhat populist platform to attract blacks' while simultaneously campaigning 'against black economic empowerment, affirmative action and minimum wages in favour of a largely unrestricted free market and more flexible labour laws' was contradictory.

Voters in the Western Cape heard the message that a vote for the NNP was, in effect, a vote for the ANC and opted to vote for the ANC. Opposition voters in 2004 did not feel pressure to vote against the ANC. Votes cast for the ANC climbed to 709052 and the party took control of the provincial government in the Western Cape under the premiership of Ebrahim Rasool.

\section{9: A BREAKTHROUGH FOR THE DA}

2009 was the DA's year in the Western Cape. With the NNP absorbed into the ANC the contest was now between the DA and the ANC. However, a DA victory was not a given - the gains it made in 2004 were seen as tentative and its successes ambiguous given the ANC's gains at the cost of the DA in areas such as Mitchells Plain (Booysen 2005, p143). There was no direct transfer of power from the NP to the DA.

In 1999 and 2004 the ANC had made significant inroads in the Western Cape, gradually gaining the trust of voters. Opposition voters did not feel a sense of urgency about keeping the ANC out of power. And as Daniel \& Southall (2009, p 237) state the ANC in the Western Cape had a significant block of loyal coloured voters. Again arguments emerged about racial polarisation in the province. Daniel \& Southall (2009, p 268) assert that 'the DA's victory came from markedly increasing its vote among the coloured community leaving the province as racially fractured as ever'.

The ANC's share of the vote dropped from 709052 to 620918 (31.5\%). Whether ANC voters had opted out and abstained or switched allegiance and voted for the DA was immaterial, the DA received an outright majority, securing 51.4 per cent. Newcomer Cope secured 7.7 per cent of the vote in the Western Cape after it became bogged down in a series of controversies regarding its policy directions and presented a 'low-key design-as-you-go' defensive election campaign (Booysen 2009, p 95-99). Nevertheless, Cope managed to surpass the ID in the Western Cape - the ID only obtained 4.7 per cent of the 2009 provincial vote.

Putting aside racial acrimony, which clearly exists, the 2009 election results in the Western Cape make sense if one considers the underlying sentiments of voters revealed by opinion polls conducted in the province in December 2008 as well as the dramatic series of events which occurred at national level. The DA's campaign of 2009, consistent with its previous hard-hitting messages, now took 
place in a completely different political context. These public sentiments were harnessed by the DA through an extremely effective election campaign.

National events between 2004 and 2009 created a situation where the DA's messages were much more salient to voters in the Western Cape. South Africans watched enthralled as Jacob Zuma, then deputy president of the country, faced a lengthy and extensively covered rape trial. While he was eventually acquitted of the rape charges some of his statements under oath about HIV made him the object of scorn and ridicule. This response, in turn, was met with virulent anger by his supporters, who thronged outside the court. The trial also resulted in hostile clashes between gender activists and supporters of Zuma.

This matter was followed by the protracted and well publicised corruption trial of Schabir Shaik, a close associate of Zuma, who was found guilty - the basis of the conviction hinging on payments he had made to Zuma. Following this conviction then president Thabo Mbeki relieved Zuma of his role as deputy president, installing Phumzile Mlambo-Ngcuka as the new deputy president. This, as Southall $(2009$, p 3) indicates, left Zuma with only his party platform from which to campaign for the presidency of the ANC, to be decided at the ANC's $52^{\text {nd }}$ national conference. In the meantime, the National Prosecuting Authority (NPA) decided to press ahead with fraud and corruption charges against Zuma. Despite this decision Zuma was elected as the ANC's new president, defeating Thabo Mbeki in his bid to remain party president. As Butler $(2009, \mathrm{p} 69)$ points out, this unprecedented defeat of an incumbent ANC president was followed by a wave of instability during which officeholders were 'recalled' and perceived Mbeki-loyalists purged. The ANC was polarised into antagonistic Mbeki and Zuma blocs (Booysen 2009, p 91). As Booysen (2009, p 90) writes, the ANC'entered a spiral of contestation between Jacob Zuma and Thabo Mbeki centring on issues of succession and incumbency'. The culmination of this contest was the removal of Thabo Mbeki from his role as president of the country.

In September 2008, just more than six months before the 2009 general elections, Judge Chris Nicholson delivered a high court judgement which inferred that Mbeki and senior members of his Cabinet had interfered with the work of the NPA in regard to the decision to prosecute Zuma (Jolobe 2009, p 139). The judgement provided the basis for a vote of no confidence in Mbeki. Following Mbeki's televised resignation ANC deputy president Kgalema Motlanthe became South Africa's acting president. These events precipitated the resignation of several ANC members and the long-anticipated split in the ANC became a reality. The Congress of the People was formed under the leadership of Mosiuoa Lekota and Mbhazima Shilowa.

Following the formation of Cope, the competitiveness of the 2009 campaign took on a new edge, with the country witnessing acrimonious and often hostile 
exchanges between Cope and the ANC. The formation of Cope publicly revealed a side of the ANC that voters were unaccustomed to - key ANC leaders lambasted Cope in a series of verbal attacks. The conflict between the two parties raised fears that the campaign would be disrupted by violence and intimidation and local election monitoring groups reconvened. The Election Monitoring Network (EMN) appointed a team of 500 politically independent community members nationwide to monitor election-related abuse or violence, empowering them to take rapid action to resolve conflict where necessary. The South African Civil Society Election Coalition (SACSEC), a national initiative of more than 40 nongovernmental and faith-based organisations committed to the conduct of free, fair and credible elections, had approximately 2000 observers observing all facets of the elections.

Reports of disrupted meetings and allegations of voter intimidation became commonplace. For example, a press statement released by the EMN reported five murders linked to political rivalry in the Eastern Cape and KwaZulu-Natal. Monitors in KwaZulu-Natal also recorded instances of traditional leaders denying political parties the right to hold meetings and forcing their subjects to join certain political parties or face eviction.

There was also heightened tension more generally, with other political parties perceiving that they could profit from the division within the ANC. Meanwhile, as Butler (2009, p 69) notes, the NPA's prosecution of Zuma on corruption and fraud charges (dropped only in March 2009) perpetuated the divisions of the succession struggle and initiated a period of 'extravagant and sometimes violenceinciting rhetoric directed at the NPA, the judiciary and purported plotters against Zuma'.

In the Western Cape these national events had a very damaging effect on perceptions of Zuma. An Afrobarometer survey conducted in late 2008 revealed that respondents in the Western Cape had very little trust in him. As figure 3 shows, only 13 per cent of respondents in the province, compared to 70 per cent in KwaZulu-Natal and 68 per cent in Mpumalanga, said they trusted Zuma 'always' or 'most of the time'.

Perceptions of the trustworthiness of a political leader are critically important because they help voters to make judgements about the authenticity and persuasiveness of the messages put out by the leader. Campaign messages delivered by political parties and leaders perceived as trustworthy will be received more positively, allowing voters to engage more positively with the content of the message. According to Newman \& Perloff (2004, p 27) 'persuasion experts unquestionably agree that the source of a message can significantly influence political attitudes'. Indeed, the literature reveals that in most situations people accept or reject persuasive messages based on their evaluation of the credibility 
Figure 3

Trust in Jacob Zuma (by province), 2008

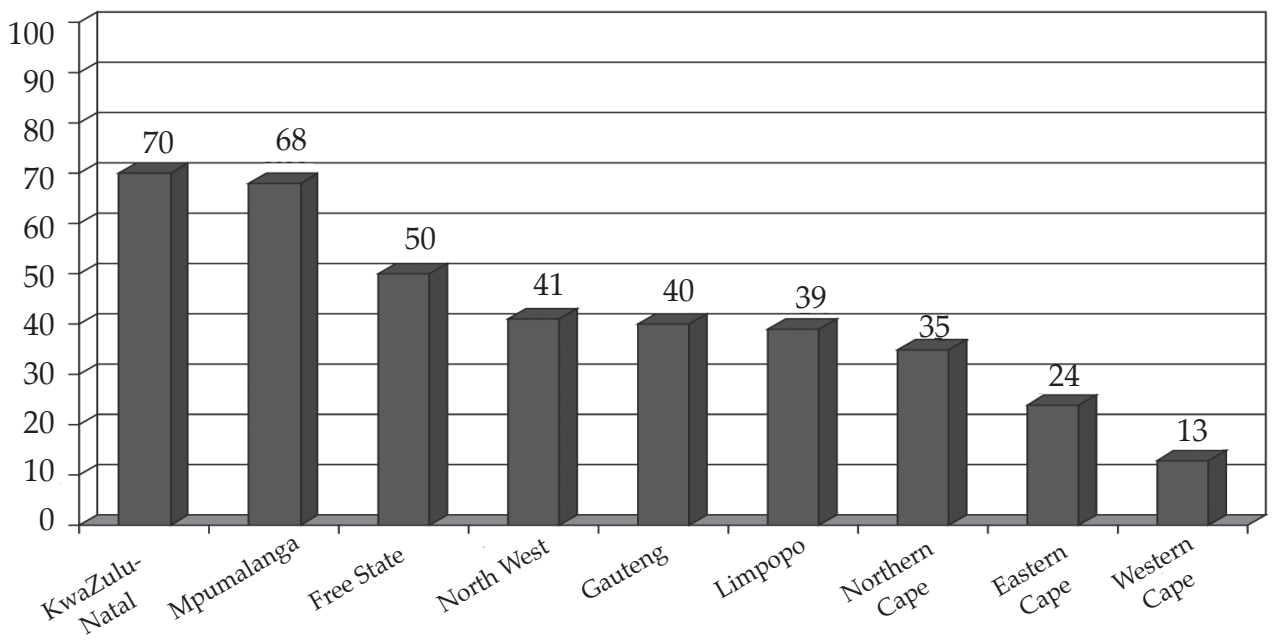

Source: Afrobarometer 2008. Sample size 2400.

of the source of the message (Milburn 1991; Lupia \& McCubbins 2000; Iyengar \& Valentino 2000; Popkin \& Dimock 2000; Newman \& Perloff 2004).

In addition to the national events outlined above ANC structures in the Western Cape were beset by their own problems. They were 'in a complete shambles and the NEC [National Executive Council] had to rescue the province after an orgy of defections, expulsions and proliferations of parallel structures' (Butler 2009, p 70). As a result, Ebrahim Rasool was removed as premier and replaced by Lynne Brown just months prior to the election. The ANC's carefullyplanned low-key campaigns of 1999 and 2004, which had successfully allayed the fears of voters in the province, were now undermined by a barrage of media images which contradicted the party's messages.

It was in this context that the DA ran a well organised and focused campaign under the banner 'One Nation One Future'. Its message could be summarised by the slogans of two campaign posters: 'Vote to win' and 'Stop Zuma' (Daniel \& Southall 2009, p 237). The party's previous election campaigns had lacked salience when there were no problems. The 1999 'fight back' campaign and the key message of 2004 that 'South Africa deserves better' could be countered as being unnecessarily dramatic or even unpatriotic, but messages about the supremacy of the Constitution and the challenges to democracy posed by ANC dominance now resonated with voters. In the Western Cape these messages clearly fell on fertile ground. 
The impact of the DA's election of Helen Zille as its new leader cannot be under estimated. Her election put to rest criticisms that the party was being pulled in different directions. Booysen (2005, p 143) had noted the perception that the DA of 2004 was divided by the divergent styles and orientations of Tony Leon and Helen Zille. Certainly Zille presented a more likeable persona, which endeared her to voters. Indeed, Jolobe $(2009$, p 31) attributes the rebranding of the DA under the leadership of Zille (who, during her term as Cape Town's mayor won the 2008 World Mayor of the Year Award) as one of the key reasons for the DA's success in the Western Cape.

Furthermore, ANC members who left to join Cope lent credibility to the DA's messages. As Booysen (2009, p 92) argues, Cope's criticisms of the ANC with regard to constitutionalism, the rule of law, and electoral reform resonated with many voters who questioned aspects of the ANC's 15-year rule. These were the very issues around which the DA had run its 1999 and 2004 campaigns.

Daniel \& Southall (2009, p 243) indicate that the ANC's monumental loss in the Western Cape could be seen as a self-inflicted disaster, 'a result of vicious factionalism which took on a racial form'. And Butler (2009, p 84) argues that the ANC 'lost the province in the worst way possible in that its action and inaction had precipitated a major and probably irreversible shift in sentiment among coloured voters'.

\section{VOTING TRENDS AND PATTERNS IN THE WESTERN CAPE, 1994-2009}

This overview of electoral trends and concomitant political developments in the Western Cape provides several useful insights. It reveals that parties in the province were primarily responsible for their own gains and losses. The results also suggest that national political developments are a crucial influence on voter perceptions. Furthermore, it appears that party behaviour, campaign messages and events between elections are important to voters. The NNP's support base was decimated by its incongruent and internally inconsistent campaign messages, organisational difficulties and national political developments between 1994 and 2004. The confidence the ANC had gradually begun to gain among voters was undermined by organisational conflict as well as by national political developments between 2004 and 2009. Although there were policy contradictions and divergent leadership styles in 2004, the DA's campaign themes have been consistent over time. In addition, the party galvanised under a new leader and vision and its campaign messages took on a new salience in 2009.

This overview also highlights a critical gap in our understanding of the interactions between political developments and the decisions made by voters. In the Western Cape it appears that voters reviewed evolving political 
developments and then rewarded and/or punished contesting parties by granting or withholding their votes. It is very hard to say which outcome would not elicit comments about racial or identity-related determinants of voting. These trends would hardly have been shocking if the region consisted of an entirely homogenous electorate. The results in the province since 1994 suggest that voters in the Western Cape are active agents who actually interpret and evaluate campaigns as well as other politically relevant stimuli. This conforms to the accountability-enhancing context described by renowned theorists Diamond \& Morlino (2005, p xix), who state that democracy requires genuinely competitive elections in which the performance of the incumbent is reviewed, policy alternatives are debated and voters reward or punish incumbents. People in the Western Cape also appear to fit Achen's (1992, p 198) description of voters who 'do not ignore information they have, do not fabricate information they do not have, and do not choose what they do not want'.

What, then, is the problem? It is that election campaigns can be used as a platform from which to evoke prejudices and fears (Kuklinski \& Quirk 2000). Election campaigns and the messages politicians send out to the electorate play a critical role in reducing or exacerbating racial or ethnic tensions. Given their preconceived notions about voting blocs, parties and political leaders can and often do engage in racially inflammatory rhetoric in attempts to win votes. This, in turn, fuels racial tension between those groups.

Clearly race and other forms of identity are a salient factor in the Western Cape. As Mattes, Giliomee and James (1996, p 149) indicate, Western Cape citizens of different race groups are confronted with very different forms of persuasion and information networks as well as different economic positions. Furthermore, in a context of scarce resources and given the fact that as Schrire (1999, p 138) points out, 'politics in all contexts involves a struggle for power between competing groups and interests over the issue of control over the instruments of power', such identities are likely to remain salient. It is precisely because of the salience of identity that political parties need to move away from racial campaign strategies.

\section{CONCLUSION}

There is a destructive cycle wherein political commentators and analysts as well as campaign strategists attach special significance to the vote of a particular demographic bloc, in this case, 'coloured voters'. These expectations feed, in turn, into the choices and actions of political parties. Perceptions of the importance of these voters also result in campaigning that encompasses unintentional or deliberate racial mobilisation and inflammatory political rhetoric. In the Western 
Cape racialised mudslinging has characterised election campaigns. While there is an Electoral Code of Conduct which commits all parties to a range of provisions related to electioneering (Lodge \& Scheidegger 2005, pp 7-8), parties still exercise a choice over the ways in which they conduct their campaigns. Thus, parties may operate within the framework of the code of conduct but continue to engage in negative practices which exacerbate the strains between groups.

After the election, results are almost invariably analysed through references to racial fault lines and the racially based motivations of voters. These explanations rest primarily on the characteristics of the electorate. Instead of reverting to the default explanation that voters vote on the basis of identity, parties need to start taking responsibility for their behaviour rather than blaming voters for their misfortunes.

Given that racial and other cleavages are important, it is incumbent upon parties to take cognisance of the negative implications of their racially inflammatory rhetoric. The incentive of electoral victory simply does not justify appeals to prejudice and fear. Not only are such appeals damaging, in many instances they plainly do not work. Parties fail when they predicate their campaign strategies on mistaken assumptions about what the 'coloured voter' wants. Parties can and should move toward more inclusive campaign strategies. Questions such as 'how do we make inroads into the coloured vote?' or 'how do we retain coloured support?' should be replaced with 'how do we promote/retain our credibility as a political party?', 'what are the most salient issues facing this region?', 'how will we deal with these issues?', 'what central message should we communicate?', 'how best can that message be communicated to voters?' and so on.

It is not voters in the Western Cape who are the problem - they are willing and able to gather and process political information. And as several authors have argued, coloured voters do not vote as a monolithic voting bloc. It is political parties that should stop blaming voters for their woes and move away from racial mobilisation, instead focusing on improving their credibility, developing defensible records and proposing policies. Finally, it is time that our analyses move to a more nuanced level which does not legitimate racialised campaign strategies and does not allow parties to neglect their duty to provide voters with adequate information. 


\section{- REFERENCES}

Achen, C H. 1992. 'Social Psychology, Demographic Variables, and Linear Regression: Breaking the Iron Triangle in Voting Research'. Political Behaviour 14(3).

Africa, C J. 1996. 'Voting in the 1994 general election: the role of race, unemployment and perceptions of violence in the Western Cape'. Unpublished thesis. University of Cape Town.

Booysen, S. 2005. 'The Democratic Alliance: Progress and Pitfalls'. In J Piombo \& L Nijzink (eds). Electoral Politics in South Africa: Assessing the First Democratic Decade. New York: Palgrave Macmillan.

- 2009. 'Congress of the People: Between Foothold of Hope and Slippery Slope'. In R Southall \& J Daniel (eds). Zunami! The 2009 South African Elections. Johannesburg: Jacana Media.

Breytenbach, W. 1999. 'The New National Party'. In A Reynolds (ed). Election '99: From Mandela to Mbeki. Cape Town: David Philip.

Butler, A. 2009. 'The ANC's National Election Campaign of 2009: Siyanqoba!'. In R Southall \& J Daniel (eds). Zunami! The 2009 South African Elections. Johannesburg: Jacana Media.

Calland, R. 1999. 'Democratic Government, South African style 1994-1999'. In A Reynolds (ed). Election '99: From Mandela to Mbeki. Cape Town: David Philip.

Daniel, J \& R Southall. 2009. ‘The National and Provincial Outcome: Continuity with Change'. In R Southall \& J Daniel (eds). Zunami! The 2009 South African Elections. Johannesburg: Jacana Media.

Davis, G. 2005. 'Media Coverage and the Election: Were some parties more equal than others?' In J Piombo \& L Nijzink (eds). Electoral Politics in South Africa: Assessing the First Democratic Decade. New York: Palgrave Macmillan.

Democratic Alliance. 2004. The Democratic Alliance 2004 General Election Manifesto. Available at: www.da.org.za/da/Site/Eng/campaigns/2004/manifesto. asp.

Diamond, L \& L Morlino. 2005. 'Introduction'. In L Diamond \& L Morlino (eds). Assessing the Quality of Democracy. Baltimore: Johns Hopkins University Press.

Edighji, O. 2004. 'Fear Versus Freedom: Minority Parties and the ANC'. Election Synopsis 1(2).

Eldridge, M \& J Seekings. 1995. An Uphill Battle: Voter Attitudes and ANC Strategy in the 1994 South African Elections. Cape Town: Centre for African Studies, University of Cape Town. 
Election Monitoring Network. 2009. Election Monitoring Network Press Statement. www.idasa.org.za/gbOutputFiles asp? WriteContent $=Y \& R I D=2518$.

Friedman S. 2005. 'A Voice for Some: South Africa's Ten Years of Democracy'. In J Piombo \& L Nijzink (eds). Electoral Politics in South Africa: Assessing the First Democratic Decade. New York: Palgrave Macmillan.

Giliomee, H. 1994. 'The National Party's Campaign for a Liberation Election'. In A Reynolds (ed). Election '94: The campaigns, results and future prospects. Cape Town: David Philip.

Government Communication and Information System. 2008. South Africa Yearbook 2007/08. South Africa: Government Communication and Information System.

Habib, A \& S Naidu. 1999. 'Election '99: Was there a "coloured" and "Indian" vote?'. Politikon 26(2).

Hoeane, T. 2004. 'Under Strain: The Racial / Ethnic Interpretation of South Africa's 2004 Election'. Journal of African Elections 3(2).

Independent Electoral Commission. 1994. '1994 National and Provincial Elections'. Available at: www.elections.org.za/content/Workarea/DownloadAsset. aspx?id=1282.

Iyengar, S \& N A Valentino. 2000. ‘Who Says What? Source Credibility as a Mediator of Campaign Advertising'. In A Lupia, M D McCubbins \& S L Popkin (eds). Elements of Reason: Cognition, Choice and the Bounds of Rationality. Cambridge: Cambridge University Press.

Johnson, R W. 1996. 'The 1994 Election: Outcome and Analysis'. In R W Johnson \& L Schlemmer (eds). Launching Democracy in South Africa. New Haven: Yale University Press.

Jolobe, Z. 2009. 'The Democratic Alliance: Consolidating the Official Opposition'. In R Southall \& J Daniel (eds). Zunami! The 2009 South African Elections. Johannesburg: Jacana Media.

Kotze, HA. 2001. 'Consummation Devoutly To be Wished: The Democratic Alliance and Its Potential Constituencies'. Democratization 8(1).

Kuklinski, J H \& P J Quirk. 2000. 'Reconsidering the Rational Public'. In A Lupia, M D McCubbins \& S L Popkin (eds). Elements of Reason: Cognition, Choice and the Bounds of Rationality. Cambridge: Cambridge University Press.

Lodge, T. 1994. 'The African National Congress and Its Allies'. In A Reynolds (ed). Election '94: The Campaigns, Results and Future Prospects. Cape Town: David Philip.

_. 1999. ‘The African National Congress'. In A Reynolds (ed). Election ‘99:From Mandela to Mbeki. Cape Town: David Philip.

-2002. Politics in South Africa: From Mandela to Mbeki. Cape Town: David Philip. 
2005. 'The African National Congress: There is no Party Like It; Ayikho Efana Nayo'. In J Piombo \& L Nijzink (eds). Electoral Politics in South Africa: Assessing the First Democratic Decade. New York: Palgrave Macmillan.

_ \& U Scheidegger. 2005. Political Parties and Democratic Governance in South Africa. EISA Research Report No 25. Johannesburg: Electoral Institute of Southern Africa.

Lupia, A \& M D McCubbins. 2000. 'The Institutional Foundations of Political Competence: How Citizens Learn What They Need to Know'. In A Lupia, MD McCubbins \& S L Popkin (eds). Elements of Reason: Cognition, Choice and the Bounds of Rationality. Cambridge: Cambridge University Press.

Magubane, B. 2000. 'Race and Democratisation in South Africa: Some Reflections'. In Y Muthien, M Khosa \& B Magubane (eds). Democracy and Governance Review: Mandela's Legacy 1994-1999. Pretoria: Human Sciences Research Council.

Mattes, R B, H Giliomee \& W James. 1996. 'The Election in the Western Cape'. In R W Johnson \& L Schlemmer (eds). Launching Democracy in South Africa. New Haven: Yale University Press.

Mattes, R B \& A Gouws. 1998. 'Race, Ethnicity, and Voting Behaviour: Lessons from South Africa'. In T D Sisk \& A Reynolds (eds). Elections and Conflict Management in Africa. Washington, DC: United States Institute of Peace Press.

Mattes, R B \& J Piombo. 2001. 'South Africa's General Election of 1999'. Democratization 8(3).

Mattes, R B, H Taylor \& C Africa. 1999. 'Judgement and Choice in the 1999 South African Election'. Politikon 26(2).

Mattes, R.B. 1995. The Election Book: Judgement and Choice in South Africa's 1994 Election. Cape Town: Institute for Democracy in South Africa.

.2005. 'Voter Information, Government Evaluations and Party Images, 19942004'. In J Piombo \& L Nijzink (eds). Electoral Politics in South Africa: Assessing the First Democratic Decade. New York: Palgrave Macmillan.

Milburn, M A. 1991. Persuasion and Politics: The Social Psychology of Public Opinion. California: Brooks Cole Publishing Company.

Newman, B I \& E M Perloff. 2004. 'Political Marketing: Theory, Research and Applications'. In L L Kaid (ed). Handbook of Political Communication Research. New Jersey: Lawrence Erlbaum Associates Inc.

New National Party. 1999. Our Blueprint for Real Democracy. South Africa: New National Party.

-2004. The NNP's CAPE PLAN 2010: Blueprint for a World-class Province. South Africa: New National Party.

-2004. Manifesto 2004: New National Party: you deserve a fair share. South Africa: New National Party. 
Ndletyana, M. 1999. 'The United Democratic Movement: A Critical Assessment'. Politikon 26(2).

Nijzink, L \& S Jacobs. 2000. 'Provincial elections and government formation in the Western Cape: The Politics of Polarisation'. Politikon 27(1).

Piombo, J. 2005. 'The Results of Election 2004: Looking Back, Stepping Forward'. In J Piombo \& L Nijzink (eds). Electoral Politics in South Africa: Assessing the First Democratic Decade. New York: Palgrave Macmillan.

Popkin, S L \& M A Dimock. 2000. 'Knowledge, Trust, and International Reasoning'. In A Lupia, M D McCubbins \& S L Popkin (eds). Elements of Reason: Cognition, Choice and the Bounds of Rationality. Cambridge: Cambridge University Press.

Reynolds, A. 1994. 'The Results'. In A Reynolds (ed). Election '94: The Campaigns, Results and Future Prospects. Cape Town: David Philip.

—. 1999. 'The Results'. In A Reynolds (ed). Election '99:From Mandela to Mbeki. Cape Town: David Philip.

SAIRR. 2007/2008. South African Survey.

Schire, R. 2001. 'The Realities of Opposition in South Africa: Legitimacy, Strategies and Consequences'. In RSouthall (ed). Democratization Special Issue: Opposition and Democracy in South Africa.

Schlemmer, L. 1999. Democracy or Democratic Hegemony? The Future of Political Pluralism in South Africa. In H Giliomee \& C Simkins (eds). The Awkward Embrace: One Party Domination and Democracy. Cape Town: Tafelberg Publishers.

Schulz-Herzenberg, C. 2005. 'The New National Party: The End of The Road'. In J Piombo \& L Nijzink (eds). Electoral Politics in South Africa: Assessing the First Democratic Decade. New York: Palgrave Macmillan.

- 2009. 'Trends in Party Support and Voting Behaviour, 1994-2009'. In R Southall \& J Daniel (eds). Zunami! The 2009 South African Elections. Johannesburg: Jacana Media.

Schnur, D. 1999. 'Greater than the Sum of Its Parts: Co-ordinating the Paid and Earned Media Message'. In B I Neuman (ed). Handbook of Political Marketing. Thousand Oaks: Sage Publications.

Silke, D \& R Schrire. 1994. 'The Mass Media and the South African Election'. In A Reynolds (ed). Election '94: The Campaigns, Results and Future Prospects. Cape Town: David Philip.

Sniderman, P M. 2000. 'Taking Sides: A Fixed Choice Theory'. In A Lupia, M D McCubbins \& S L Popkin (eds). Elements of Reason: Cognition, Choice and the Bounds of Rationality. Cambridge: Cambridge University Press.

Southall, R. 1998. 'The Centralization and Fragmentation of South Africa's Dominant Party System'. African Affairs 97(389). 
- 2009. 'Zunami! The Context of the 2009 Election'. In R Southall \& J Daniel (eds). Zunami! The 2009 South African Elections. Johannesburg: Jacana Media.

_ \& J Daniel. 2005. 'The State of Parties Post-election 2004: ANC Dominance and Opposition Enfeeblement'. In J Daniel, R Southall \& J Lutchman (eds). State of the Nation South Africa: 2004-2005. Cape Town: HSRC Press.

Taylor, R \& T Hoeane. 1999. 'Interpreting the South African Election of June 1999'. Politikon 26(2).

Weaver, M R. 1996. 'Paid Media'. In D M Shea (ed). Campaign Craft: The Strategies, Tactics, and Art of Political Campaign Management. Westport, Conn: Praeger Publishers.

Welsh, D. 1994. 'The Democratic Party'. In A Reynolds (ed). Election '94: The Campaigns, Results and Future Prospects. Cape Town: David Philip. 